\title{
Estrogen Receptor Alpha Expression in Ovarian Cancer Predicts Longer Overall Survival
}

\author{
Agnieszka Halon • Verena Materna • Malgorzata Drag-Zalesinska • \\ Ewa Nowak-Markwitz • Tserenchunt Gansukh • Piotr Donizy • Marek Spaczynski • \\ Maciej Zabel • Manfred Dietel $\cdot$ Hermann Lage $\cdot$ Pawel Surowiak
}

Received: 9 August 2010 /Accepted: 24 November 2010 /Published online: 6 January 2011

(C) The Author(s) 2011. This article is published with open access at Springerlink.com

\begin{abstract}
Estrogen as a potential factor of ovarian carcinogenesis, acts via two nuclear receptors, estrogen receptor alpha $(\mathrm{ER} \alpha)$ and estrogen receptor beta $(\mathrm{ER} \beta)$, but the cellular signal pathways involved are not completely clear so far. In this study we have described the expression of $\mathrm{ER} \alpha$, detected by immunocytochemistry in 11 ovarian carcinoma cell lines and by immunohistochemistry in 43 Federation Internationale des Gyneacologistes et Obstetristes stage III ovarian carcinoma specimens prepared before and after treatment with cisplatin-based schemes. For cisplatin resistance is a major obstacle in the treatment of ovarian carcinoma, analysis of cisplatin sensitivity in 11 ovarian carcinoma cell line was also performed. The strong nuclear ER $\alpha$ expression was only shown in the single A2780P cell line. Expression of ER $\alpha$ in tissue specimens did not reveal any correlations between histopathological
\end{abstract}

A. Halon $(\bowtie) \cdot$ P. Donizy

Department of Pathomorphology, Wroclaw Medical University,

ul. Marcinkowskiego 1,

50-367 Wroclaw, Poland

e-mail: ahalon2@gmail.com

V. Materna $\cdot$ M. Dietel $\cdot$ H. Lage $\cdot$ P. Surowiak Charité Campus Mitte, Institute of Pathology,

Chariteplatz. 1 20/21,

10117 Berlin, Germany

M. Drag-Zalesinska $\cdot$ M. Zabel $\cdot$ P. Surowiak Department of Histology and Embryology,

Wroclaw Medical University,

ul. Chalubinskiego 6a,

50-356 Wroclaw, Poland

E. Nowak-Markwitz $\cdot$ M. Spaczynski

Department of Obstetrics and Gynaecology,

University School of Medicine,

ul. Polna 33,

60-535 Poznan, Poland parameters (histologic type and grading). We demonstrated a significant association with ER $\alpha$ expression in specimens from primary laparotomies (PL) and cause-specific survival. In the cases terminated by death of the patient, overall immunoreactivity score of $\mathrm{ER} \alpha$ expression at PL was significantly lower than in surviving patients. In addition, Kaplan-Meier analysis revealed significantly shorter overall survival time and progression-free time in cases with lower immunoreactivity score of $\mathrm{ER} \alpha$ expression at PL. Our findings support the hypothesis that aberrant hormone activity, by way of altered receptor expression, might be an important factor in the malignant transformation of ovarian cancer.

Keywords Estrogen receptor alpha - Ovarian cancer . Immunohistochemistry Cisplatin

\section{T. Gansukh}

Medical Research Institute of Mongolia, Bayangol duureg, Ard-Ayush Street-1, 210526 Ulan Bator, Mongolia

\footnotetext{
M. Zabel University School of Medicine, ul. Swiecickiego 6, 60-781 Poznan, Poland

P. Surowiak

Lower Silesian Oncology Centre,

pl. Hirszfelda 12,

53-413 Wroclaw, Poland
}

Department of Histology and Embryology, 


\section{Introduction}

Ovarian cancer is the leading cause of death from gynecological malignancies in Western countries. About 190,000 new cases and 114,000 deaths from ovarian cancer are estimated to occur annually. The highest rates are reported in Scandinavia and Eastern Europe, the USA, and Canada [1]. One of the reasons for the poor prognosis is high rate of advanced tumors at the time of diagnosis: about $75 \%$ of all patients are diagnosed in FIGO stage III or IV.

High serum levels of estrogen have been implicated as a risk factor for ovarian carcinoma, but the cellular signal pathways involved are not completely clear so far. The most commonly considered hypothesis of ovarian carcinogenesis proposes that incessant ovulatory cycles lead to long-term exposure of the epithelium to an estrogen-rich enviroment, which may promote cellular proliferation, inclusion cyst formation, and possibly malignant transformation [2].

Estrogen acts via two nuclear receptors, estrogen receptor alpha $(E R \alpha)$ and estrogen receptor beta $(E R \beta)$ which are coded from two separate genes, $E R \alpha$ and $E R \beta$, located on chromosomes $6 \mathrm{q} 25.1$ and $14 \mathrm{q} 22-24$, respectively [3]. Previous studies of normal and malignant human ovaries have provided incoherent results. Pujol et al. [4] have showed an increase in ER $\alpha$ mRNA relative to ER $\beta$ in ovarian cancer compared to normal tissue. Another study has revealed lower levels of ER $\beta$ in ovarian epithelial primary tumors, and only ER $\alpha$ in metastatic tumors [5]. Substantially, many studies have demonstrated that ER $\beta$ is highly represented in normal epithelial ovarian cells or benign tumors [4, 6-8], whereas $\mathrm{ER} \alpha$ is the main form expressed in malignant tumors [6]. Further studies are needed to fully determine the contributions of ERs to ovarian cancer.

Only $15-18 \%$ of ER-positive ovarian cancer initially respond to anti-estrogen treatment based on blocking of estrogen-ER binding, in contrast to effective treatment of about $50 \%$ of ER-positive breast cancer [9]. The most common mechanism of antiestrogen resistance is absence of estrogen receptors. From the previous data, the role of tamoxifen in ovarian cancer has not been properly evaluated, although some authors postulated that combined therapy with cisplatin and tamoxifen might reduced cisplatin resistance $[10,11]$

\section{Material and Methods}

\section{Cell Culture}

Human carcionoma cells were grown in Leibovitz L-15 medium (Biowhittaker, Walkersville, MD) supplemented by $10 \%$ fetal calf serum (FCS) (GIBCO/BRL, Grand Island, NY), $1 \mathrm{mM} \mathrm{L-glutamine,} 6.25 \mathrm{mg} / 1$ fetuin, $80 \mathrm{IE} / 1$ insulin, $2.5 \mathrm{mg} / \mathrm{ml}$ transferrin, $0.5 \mathrm{~g} / 1$ glucose, $1.1 \mathrm{~g} / 1 \mathrm{NaHCO}_{3}, 1 \%$ minimal essential vitamins and $20,000 \mathrm{kIE} / 1$ trasylol in a humidified atmosphere of $5 \%$ $\mathrm{CO}_{2}$ at $37^{\circ} \mathrm{C}$ as described previously [12-15]. The cisplatin-resistant cell line, A2780RCIS, was derived from the ovarian carcinoma cell line, A2780 [12]. The human ovarian carcinoma cell lines CAOV-3, EFO 21, EFO 27, ES2, Mdah 2774, OAW 42, OVCAR-3, PA-1, and SKOV-3 were kindly provided by Dr. Carsten Denkert (Institute of Pathology, Charité, Berlin, Germany). In order to ensure maintenance of cisplatin-resistant phenotype of A2780RCIS cells, the medium was supplemented with $10 \mathrm{Ag} / \mathrm{mL}$ of cisplatin (33.3 $\mu \mathrm{mol} / \mathrm{L}$; GRY-Pharm, Kirchzarten, Germany).

\section{Cell Proliferation Assay}

Chemoresistance was tested using a proliferation assay based on sulphorhodamine B (SRB) staining as described previously [16]. Briefly, 800 cells per well were seeded in 96-well plates in triplicates. After $24 \mathrm{~h}$ attachment, cisplatin (GRY-Pharm, Kirchzarten, Germany) was added in dilution series for a 5-day incubation, before SRB staining was performed. Incubation with cisplatin was terminated by replacing the medium with $10 \%$ trichloroacetic acid, followed by incubation at $4^{\circ} \mathrm{C}$ for $1 \mathrm{~h}$. Subsequently, the plates were washed five times with water and stained by adding $100 \mu \mathrm{l} 0.4 \%$ SRB (Sigma, St. Louis, MO, USA) in $1 \%$ acetic acid for $10 \mathrm{~min}$ at room temperature. Washing the plates five times with $1 \%$ acetic acid eliminated unbound dye. After air-drying and re-solubization of the proteinbound dye in $10 \mathrm{mM}$ Tris- $\mathrm{HCl}(\mathrm{pH}=8.0)$ absorbance was read at $562 \mathrm{~nm}$ in an Elisa-Reader (EL 340 Microplate Bio Kinetics Reader, BIO-TEK Instruments, Winooski, VT, USA). The measurements were performed in triplicates in three independent experiments. $\mathrm{IC}_{50}$-values were calculated from three independent experiments for each cell line.

\section{Patients}

Immunohistochemical examination was performed retrospectively on tissue samples taken for routine diagnostic purposes. Forty three patients operated in 1999-2002 due to ovarian carcinoma in the Department of Gynaecology and Obstetrics, University Medical School in Poznan, Poland were included in the study. The cases were selected based on availability of tissue and were not stratified for known preoperative or pathological prognostic factors. The study was approved by an Institutional Review Board (IRB) and the patients gave their informed consent before their inclusion into the study. Following the primary laparotomy (PL) all the patients were subjected to chemotherapy using 
cisplatin-based schemes (Table 1). Thirty six patients from the same group were subjected also to the secondary cytoreduction (SCR). In 7 cases no second-look procedure was performed due to advancement of the disease. In 6 cases no tumour cells were detected in the material originating from the second-look procedure. The patients were monitored by periodic medical check-ups, CA-125 serum levels, ultrasonographic and radiological examinations. During the follow-up period, 22 patients $(51 \%)$ had a recurrent disease and 13 patients $(30 \%)$ died of the disease. The mean (median) progression-free survival time was 16.9 months (range 0-52 months), while the mean (median) overall-free survival time was 24.6 months (range 652 months). Only 1 stage I and 1 stage II patients achieved optimal cytoreduction.

Tissue samples were fixed in $10 \%$ buffered formalin and embedded in paraffin. In each case, hematoxylin and eosin stained preparations were subjected to histopathological evaluation by two pathologists. The stage of the tumors was assessed according to the International Federation of Gynaecology and Obstetrics [17]. Tumors were graded according to the Silverberg grading system [18].

Table 1 Patient and tumor characteristics

\begin{tabular}{|c|c|c|}
\hline Characteristics & No. $(\%)^{\mathrm{c}}$ & \\
\hline All patients & & $43(100)$ \\
\hline \multirow[t]{3}{*}{ Age $(\text { mean } 51.0)^{\mathrm{a}}$} & $\leq 50$ & $20(47)$ \\
\hline & $50-60$ & $16(37)$ \\
\hline & $>60$ & 7 (16) \\
\hline \multirow[t]{3}{*}{ Grade $^{a}$} & 1 & $7(16)$ \\
\hline & 2 & $18(42)$ \\
\hline & 3 & $18(42)$ \\
\hline \multirow[t]{3}{*}{$\mathrm{FIGO}^{\text {a }}$} & I & $1(2)$ \\
\hline & II & $1(2)$ \\
\hline & III & $41(95)$ \\
\hline \multirow[t]{3}{*}{ Histology ${ }^{a}$} & Serous & $37(86)$ \\
\hline & Endometrioid & $3(7)$ \\
\hline & Other & $3(7)$ \\
\hline \multirow[t]{3}{*}{ Clinical response ${ }^{\mathrm{b}}$} & Complete response & $16(37)$ \\
\hline & Stable disease & $5(12)$ \\
\hline & Progressive disease & $22(51)$ \\
\hline \multirow{5}{*}{$\begin{array}{l}\text { Chemotherapy } \\
\text { (in total) }\end{array}$} & Cisplatin/Paclitaxel & $31(72)$ \\
\hline & $\begin{array}{l}\text { Cisplatin/Cyclophosphamide/ } \\
\text { Adriblastin }\end{array}$ & $6(14)$ \\
\hline & $\begin{array}{l}\text { Cisplatin/Cyclophosphamide/ } \\
\text { Paclitaxel }\end{array}$ & $3(7)$ \\
\hline & $\begin{array}{l}\text { Cisplatin/Cyclophosphamide/ } \\
\text { Paclitaxel/Adriblastin }\end{array}$ & $2(5)$ \\
\hline & Carboplatin/Paclitaxel & $1(2)$ \\
\hline
\end{tabular}

\footnotetext{
${ }^{a}$ Data are given for the first operation/diagnosis implemented

${ }^{\mathrm{b}}$ According to RECIST (Response Evaluation Criteria in Solid Tumours) [29]

${ }^{\mathrm{c}}$ Differences in the sum to $100 \%$ in groups are due to rounding
}

Immunohistochemistry

Formalin-fixed, paraffin embedded tissue was freshly cut $(4 \mu \mathrm{m})$. The sections were mounted on Superfrost slides (Menzel Gläser, Germany), dewaxed wtih xylene, and gradually hydrated. Activity of endogenous peroxidase was blocked by $5 \mathrm{~min}$ exposure to $3 \% \mathrm{H}_{2} \mathrm{O}_{2}$. All the studied sections were boiled for $15 \mathrm{~min}$ at $250 \mathrm{~W}$ in the Antigen Retrieval Solution (DakoCytomation, Denmark). Then, immunohistochemical reactions were performed using the mouse monoclonal (clone 1D5) antibodies detecting ER $\alpha$ (optimaly prediluted) (DakoCytomation, Denmark). Tested sections were incubated with antibodies for $1 \mathrm{~h}$ at room temperature. Subsequent incubations involved biotinylated antibodies $(15 \mathrm{~min}$, room temperature) and streptavidin-biotinylated peroxidase complex (15 min, room temperature) (LSAB+, HRP, DakoCytomation, Denmark). NovaRed (Vector Laboratories, UK) was used as a chromogen (10 min, at room temperature). All the sections were counterstained with Meyer's hematoxylin. On every case, control reactions were included, in which specific antibody was substituted by the Primary Mouse Negative Control (DakoCytomation, Denmark).

Control reactions were also performed on paraffin sections from six breast cancer cases, known as estrogen receptor positive (from the archive of the Department of Pathology, Lower Silesian Centre of Oncology).

Immunocytochemistry

Immunostaining of ER $\alpha$ was performed using all the studied cell lines. Cells were grown on microscope slides and fixed in ice-cold methanol-acetone mixture (1:1) for $10 \mathrm{~min}$. After re-hydration, immunostaining reaction was performed in triplicate as described above.

Evaluation of Reaction Intensity

Intensity of immunohistochemical reactions was estimated independently by two pathologists. In doubtful cases a reevaluation was performed using a double-headed microscope and staining was discussed until a consensus was achieved. In order to evaluate the ER $\alpha$ expression a semi-quantitative scale of ImmunoReactive Score (IRS) was applied, in which intensity of colour reaction and percentage of positive cells were taken into account. The score represented a product of points given for the evaluated characters and it ranged from 0 to 12 [19] (Table 2). Cases with expression of 0 to 2 in IRS scale [19-21] were treated as negative cases.

Statistical Analysis

Statistical analysis of the results took advantage of Statistica 98 PL software (Statsoft, Poland). The employed 
Table 2 Procedure for evaluation of estrogen receptor alpha expression using IRS (ImmunoReactive Score) score [19]

\begin{tabular}{llll}
\hline Percentage of positive cells & Points & Intensity of reaction & Points \\
\hline No positive cells & 0 & No reaction & 0 \\
$<10 \%$ positive cells & 1 & Weak colour reaction & 1 \\
$10-50 \%$ positive cells & 2 & Moderate intensity & 2 \\
$51-80 \%$ positive cells & 3 & Intense reaction & 3 \\
$>80 \%$ positive cells & 4 & & \\
\hline
\end{tabular}

tests included U Mann-Whitney's test and Chi ${ }^{2}$. KaplanMeier's statistics and log-rank tests were performed using SPSS software (release 10.0; SPSS Inc., Chicago, IL, USA) to estimate significance of differences in survival times. The length of progression-free survival was defined as the time between the primary surgical treatment and diagnosis of a recurrent tumor or death. Since we have not found with an univariate analysis any significant relationships between studied clinicopathological parameters (age, histology, grade, CA-125 at PL level) and overall survival and progression free time of studied patients $(P>0.05)$, we have not performed a multivariate analysis. Since $95 \%$ of the studied patients were in stage FIGO III, we have not investigated relationships between stage and survival data.

We have also performed Kaplan-Meier's statistics and log-rank tests on subgroup of 35 FIGO III patients receiving post-surgical platinum and paclitaxel containing combination therapy.

\section{Results}

\section{Cisplatin-Sensitivity of Studied Cell Lines}

Table 3 shows $\mathrm{IC}_{50}$ values of studied cell lines for cisplatin (Table 3).

Table 3 Chemosensitivity to cisplatin ( $\mathrm{IC}_{50}$ value) and immunoreactivity score of ER $\alpha$ expression in human ovarian carcinoma cell lines

\begin{tabular}{lcc}
\hline Cell line & $\mathrm{IC}_{50}[\mu \mathrm{M}]$ & ER $\alpha[$ IRS score $]$ \\
\hline A2780P & 23.87 & 12 \\
A2780RCIS & 98.98 & 0 \\
CAOV-3 & 1.92 & 0 \\
EFO 21 & 5.08 & 0 \\
EFO 27 & 2.25 & 0 \\
ES-2 & 7.64 & 0 \\
Mdah 2774 & 6.36 & 0 \\
OAW 42 & 5.49 & 0 \\
OVCAR-3 & 1.88 & 0 \\
PA-1 & 0.75 & 0 \\
SKOV-3 & 18.85 & 0 \\
\hline
\end{tabular}

The studied ovarian carcinoma cells have shown a broad variety of cisplatin-sensitivity. Majority of them showed a relatively good response to the cisplatin, with the exception of the A2780RCIS, A2780P and SKOV-3 cell lines $\left(\mathrm{IC}_{50}=98.98,23.87\right.$ and 18.85 respectively).

$\mathrm{ER} \alpha$ Immunostaining in Studied Cell Lines

We have shown the strong nuclear expression (score 12) $\mathrm{ER} \alpha$ in A2780P cell line. The other studied cell lines were $\mathrm{ER} \alpha$ negative. So, we have not studied the relationships between $\mathrm{ER} \alpha$ expression and cisplatin-sensitivity of studied cell lines.

ER Immunostaining in Control Preparations and in Ovarian Cancers

Control reactions performed on the sections of human breast cancers demonstrated a strong reaction of nuclear localisation in neoplastic cells. In the case of studied ovarian cancers, reaction of nuclear location was obtained, of variable intensity in individual cases (Fig. 1a and b). Mean overall immunoreactivity score of $\mathrm{ER} \alpha$ expression amounted to $2,837 \pm$ 2,894 SD (min. 0, max. 12) in PL material and 2,533 $\pm 2,738$ $\mathrm{SD}$ (min. 0, max. 12) in SCR material (Fig. 2).

At the first stage of statistical analysis the MannWhitney's U test was employed to compare overall immunoreactivity score of $\mathrm{ER} \alpha$ expression at PL and SCR. We have found no significant differences $(P>0.05)$.

Using the $\mathrm{Chi}^{2}$ test, relationships were examined between overall immunoreactivity score of ER $\alpha$ expression on one hand and histological type of the tumour and grade on the other. No significant relationships were detected (Table 4). Spearman's rank correlation demonstrated no relationships between overall immunoreactivity score of $\mathrm{ER} \alpha$ expression at PL and at SCR on one hand and patients age on the other (Table 4).

\section{ER Expression and Patients Survival}

At the first stage of statistical analysis of relationships between ER $\alpha$ expression and survival of the patients, $\mathrm{Chi}^{2}$ test was used. The relations were examined between overall immunoreactivity score of $\operatorname{ER} \alpha$ expression on one hand 


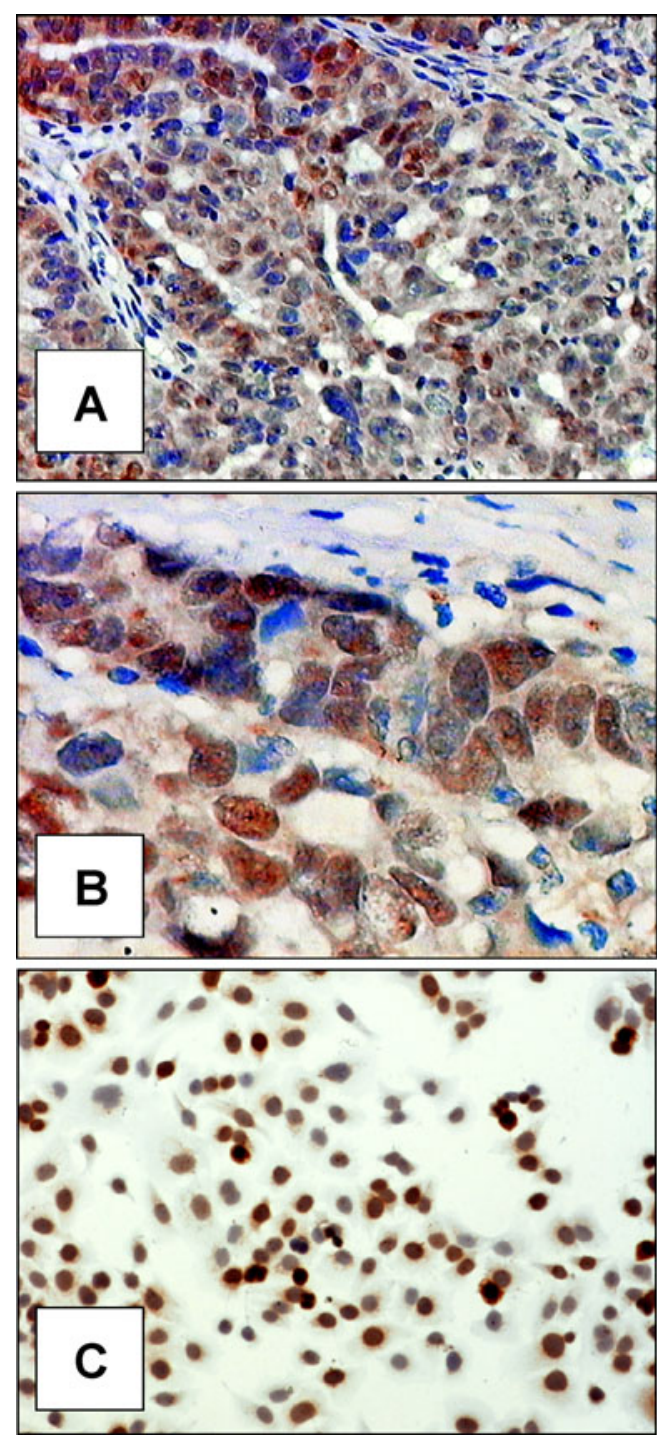

Fig. 1 Immunohistochemical localisation of $\mathrm{ER} \alpha$ expression in ovarian cancer tissue $(\mathbf{a} ., \times 200, \mathbf{b}$., $\times 400$; hematoxylin) and in the cells A2780P (c., $\times 200$; hematoxylin)

and clinical response to chemotherapy, relapses and patient deaths on the other. In the cases terminated by death of the patient overall immunoreactivity score of ER $\alpha$ expression at PL was significantly lower $(P=0.003)$ than that in surviving patients (Table 4).

In Kaplan-Meier's analysis overall survival time and progression-free time were compared between cases showing lower (IRS 0-2) and higher (IRS 3-12) overall immunoreactivity score of $\mathrm{ER} \alpha$ expression at PL and SCR. The analysis demonstrated that significantly shorter overall survival time and progression-free time characterized cases with lower overall immunoreactivity score of ER $\alpha$ expression at PL (Fig. $3 a$ and b). In sections originating from SCR no significant relationship could be detected between overall immunoreactivity score of ER $\alpha$ expression and patients survival (Fig. 3c and d).
In the subgroup of 35 FIGO III patients receiving postsurgical platinum and paclitaxel containing combination therapy the analysis has shown no significant relationships between ER $\alpha$ expression and overall survival time and progression-free time (Table 5).

\section{Discussion}

In this study we have described the expression of ER $\alpha$, detected by immunohistochemistry in malignant epithelial ovarian tumours, in the sections originating from primary laparotomies and secondary cytoreductions.

Expression of ER $\alpha$ did not reveal any correlations between histopathological parameters, such as histologic type of tumors and ovarian cancer grading. Interestingly, we demonstrated a significant association with ER $\alpha$ expression in specimens from PL and cause-specific survival. In the cases terminated by death of the patient, overall immunoreactivity score of $\mathrm{ER} \alpha$ expression at PL was significantly lower than in surviving patients. In addition, Kaplan-Meier analysis revealed significantly shorter overall survival time and progression-free time in cases with lower immunoreactivity score of ER $\alpha$ expression at PL. We have found no association between these parameters and sections originating from SCR.

$\mathrm{ER} \alpha$ expression has been studied extensively in ovarian cancer to correlate it to clinico-pathological parameters and prognosis [1, 3, 6, 22 24, 25]. Despite that, no clear relationship between immunohistochemical status of ER $\alpha$, tumor parameters and outcome has been noted in ovarian cancer.

Lee et al. [23] demonstrated that expression of receptors for estrogen did not show an effect on survival, only progesterone receptor (PR) was an independent marker, with its overexpression associated with favorable prognosis in patients with ovarian cancer.

Li et al. [24] made researches on ovarian cells cultures, identified a 2-fold up-regulation of $\mathrm{ER} \alpha$ protein that was relative to ER $\beta$ in primary cells cultures, that are derived from epithelial ovarian cancer. These finding reflect differences between normal and malignant primary cultures and support an association between the up-regulation ER $\alpha$ in ovarian carcinogenesis.

On the other hand, Hecht et al. [25] have revealed no relationship between ER $\alpha$ expression and clinico-pathological parameters, such as tumor invasion, grade and stage.

Our results presented here are in accordance with Burges et al. [22], investigating ER $\alpha$ expression by immunohistochemistry. In this study, univariate survival analysis revealed that patients with positive-ER $\alpha$ status had a significant better progression-free survival compared with the patients with no expression. Additionally, patients with 
Fig. 2 Expression of ER $\alpha$ a at primary laparotomy and $\mathbf{b}$ at secondary cytoreduction and clinical and pathological data on the patients. $C R$ :complete response, $S D$ stable disease, $P D$ progressive disease
A

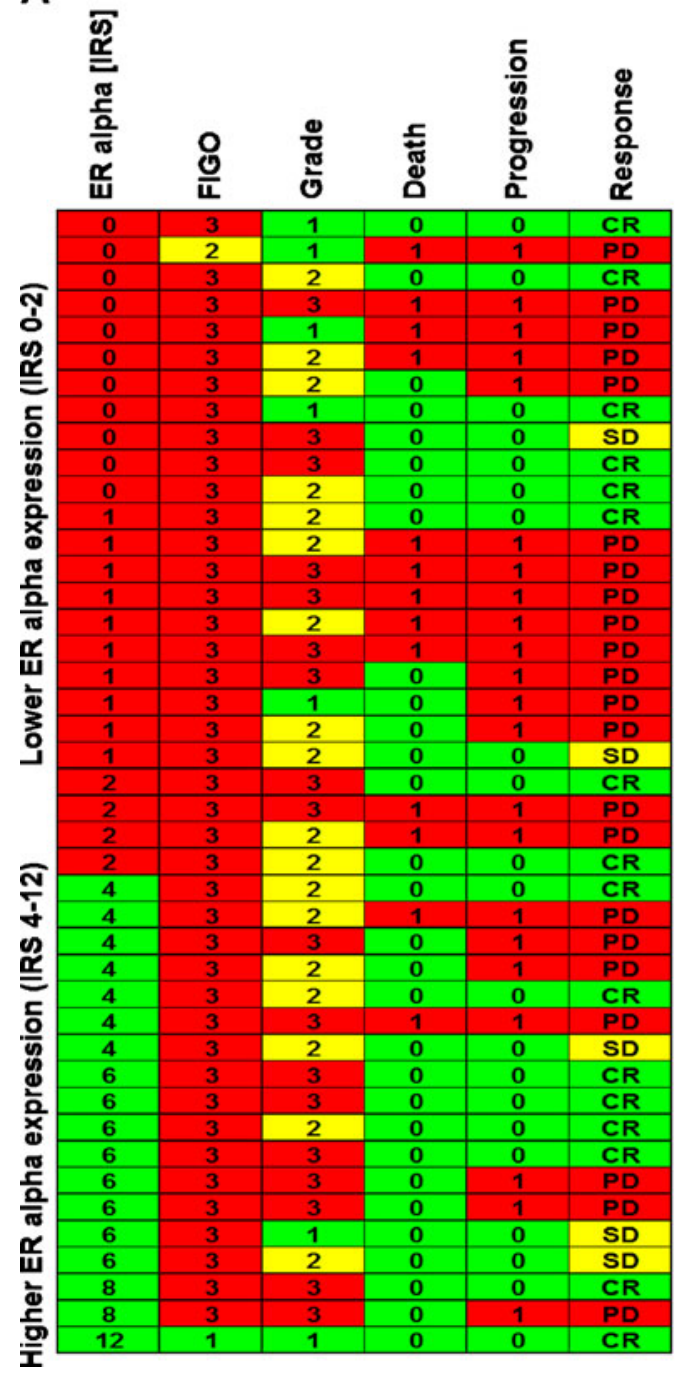

B

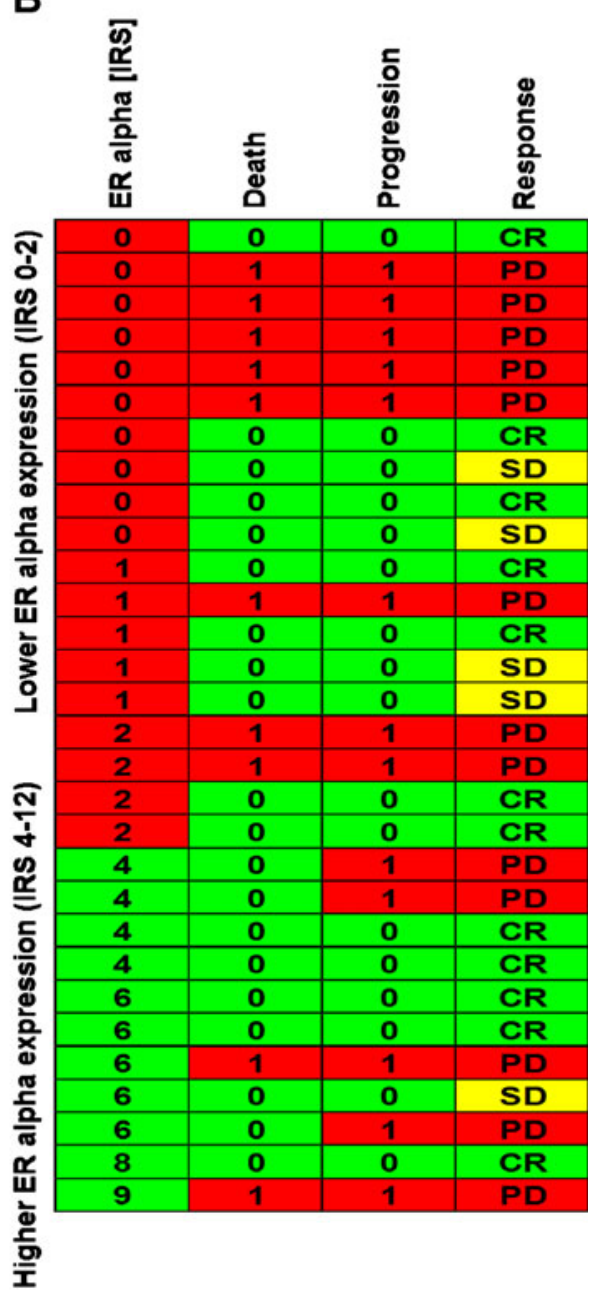

low immunoreactive score of ER $\alpha$ expression characterized a highly significant poorer cause-specific survival. Interestingly, high level of ER $\alpha$ expression demonstrated a significant association with grading [22].

Table 4 Correlation between estrogen receptor alpha expression and various clinicopathologic parameters

\begin{tabular}{lcc}
\hline Characteristics & $\begin{array}{l}\text { Primary laparotomy } \\
(\mathrm{PL}) \mathrm{P} \text { value } \mathrm{Chi}^{2} \text { test }\end{array}$ & $\begin{array}{l}\text { Secondary cytoreduction } \\
\text { (SCR) P value Chi }{ }^{2} \text { test }\end{array}$ \\
\hline Histologic type $^{\text {Grade }}{ }^{\text {a }}$ & 0.4271 & - \\
Clinical response $_{\text {Age }}{ }^{\mathrm{b}}$ & 0.2768 & - \\
Relapse & 0.5367 & 0.6557 \\
Death & 0.1343 & 0.7992 \\
\hline
\end{tabular}

$P L$ first-look laparotomy; SCR secondary cytoreductions

${ }^{a}$ The relationships between ER expression at SCR on one hand and histologic type and grade on the other was not examined

b Spearman's rank correlation
Despite several in vitro studies which investigated ovarian cancer tissues and human ovarian cancer cell lines exist [24-28], exact mechanism of ovarian tumorigenesis is not well known. In our study, we have shown the strong nuclear expression (score 12) ER $\alpha$ only in A2780P cell line. The other studied cell lines were $\mathrm{ER} \alpha$ negative. Additionally, investigated cell lines have shown a broad variety of cisplatin sensitivity. Majority of them revealed a relatively good response to the cisplatin, with the exception of the A2780RCIS, A2780P and SKOV-3 cell lines. So, we have not studied the relationship between ER $\alpha$ expression and cisplatin sensitivity of studied cell lines.

Conflicting effects from various studies and clinical trials about role of $\mathrm{ER} \alpha$ in ovarian carcinogenesis may come from differences in methodology and existence of undefined factors, which are involved in tumor progression. Intriguing results documenting estrogen impact on ovarian cancer and significance of $\mathrm{ER} \alpha$ expression in promotion of tumor progression have Chao et al [27]. They investigated potential role of estrogen and progesterone in the OC-117- 
Fig. 3 Kaplan-Meier curves for survival and expression of ER $\alpha$ in studied group of 43 ovarian cancer patients: Patients with higher overall immunoreactivity score of $\mathrm{ER} \alpha$ expression at PL have an increased overall survival time (a) and an increased progression-free time (b). No significant differences in overall survival time (c) and progression-free time (d) between patients with lower and higher overall immunoreactivity score of ER $\alpha$ expression at SCR
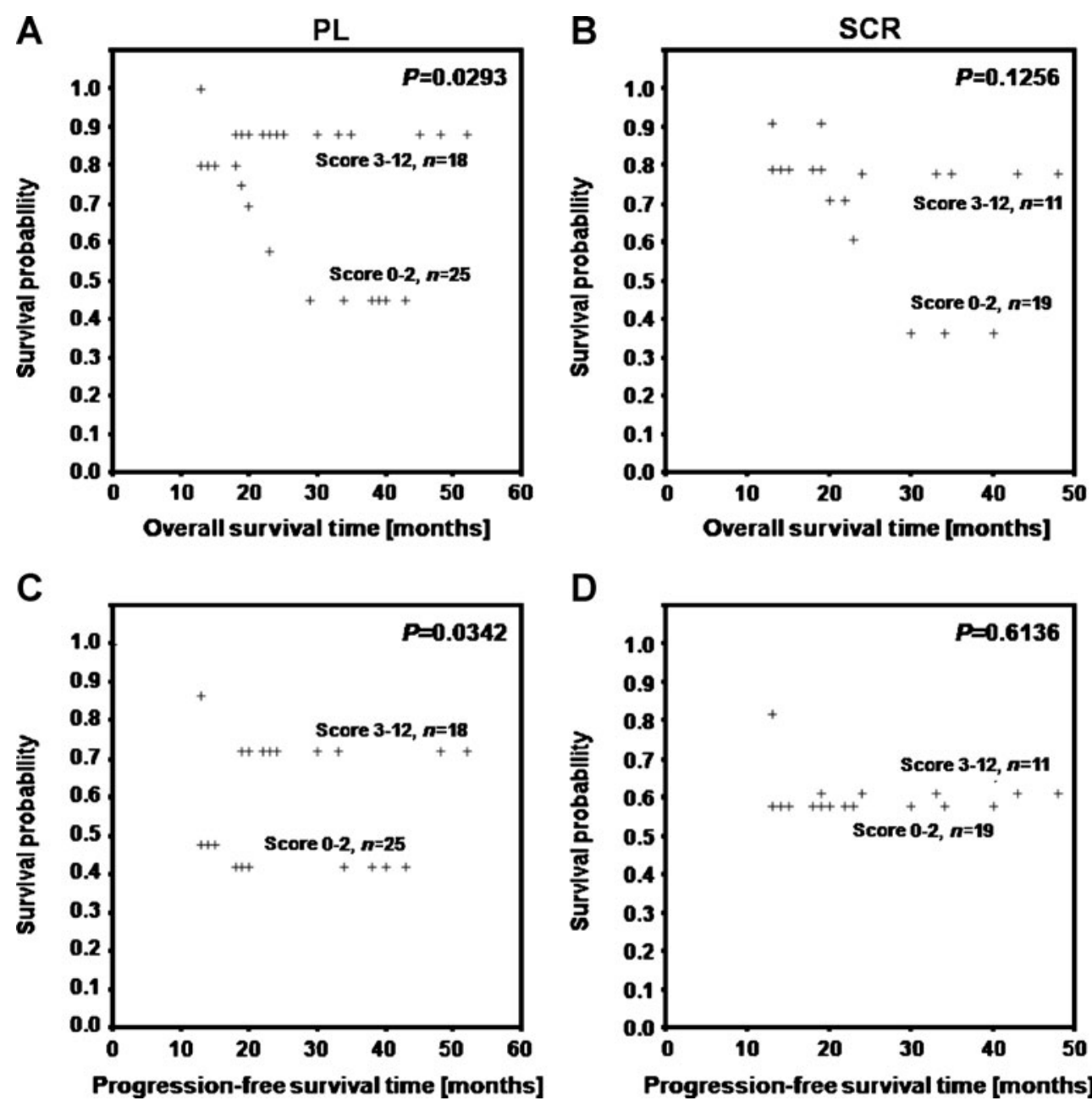

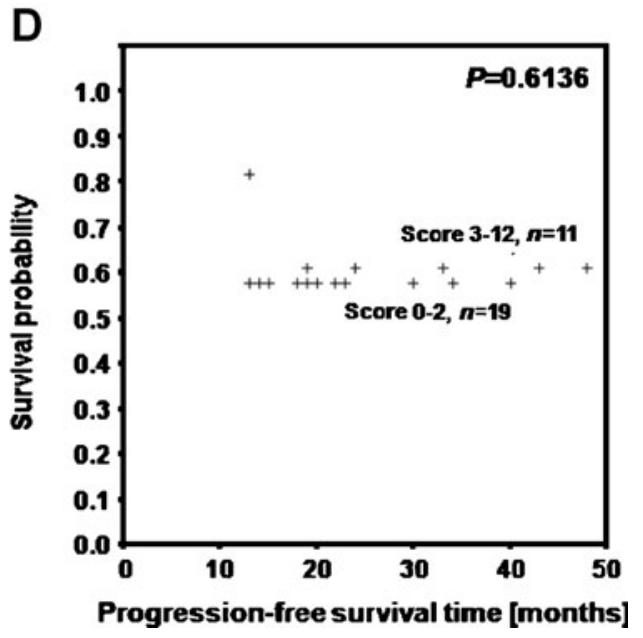

VGH human ovarian adenocarcinoma cell line, which was negative for ER $\alpha, E R \beta$ and PR. Furthermore, serial concentrations of estrogen and progesterone were used to evaluate their effects on the survival of ovarian cancer cell line. Paradoxically, these results showed that the OC-117-VGH cell line was sensitive to estrogen inhibition of growth and proliferation through down-regulation of anti- and proapoptotic genes Bcl-2 and Bax. This phenomenon was definitely associated with ER $\alpha$-independent pathway. Interestingly, estrogen treatment in this cell line had a negative

Table 5 Relationships between overall survival time (OS) and progression-free survival (PFS) and expression of ER $\alpha$ in the subgroup of FIGO stage III patients treated with platinum-based drugs and paclitaxel

\begin{tabular}{lll}
\hline & PL, $\mathrm{n}=35$ & SCR, $\mathrm{n}=24$ \\
\hline Score & Score 0-2 $\mathrm{n}=18$ & Score 0-2 $\mathrm{n}=15$ \\
& Score 3-12 $\mathrm{n}=17$ & Score 3-12 $\mathrm{n}=9$ \\
Overall survival & $P=0.2352$ & $P=0.0633$ \\
Progression-free survival & $P=0.1894$ & $P=0.7324$ \\
\hline
\end{tabular}

effect on tumor survival, so estrogen may also directly affects cell growth and proliferation without binding to its relevant receptor $\mathrm{ER} \alpha$ [27]. In the light of this experimental results, further studies are needed to fully determine the contribution of estrogen and $\mathrm{ER} \alpha$ to ovarian cancer.

However, it should be noted that high expression of ER $\alpha$ as a important factor that could be responsible for promoting ovarian tumor progression, have been reported in previous studies [1, 2, 26, 28]. Park et al. [28] additionally revealed that $17 \beta$-estradiol (E2) treatment, exclusively through an ER $\alpha$-dependent pathway led to increasing the metastatic propensity of human epithelial ovarian cancer cell lines and enhanced cell migratory potential. This cytomorphological and functional alterations were significantly associated with up-regulation of Snail and Slug - the leading epithelial-mesenchymal transition (EMT) transcription factors, and down-regulation of E-cadherin as a one of the best-characterized markers of EMT and tumor suppressor. This study provides that ovarian carcinogenesis is a multistep process, in which are involved a lot of biological factors and $\mathrm{ER} \alpha$ can potentiate tumor progression by EMT induction. 
Possibly way of explanation this immunohistochemical contradiction is fact that estrogens have a cancer-promoting effect during early stage in ovarian carcinogenesis, but during cancer progression other malignant factors might supplant preponderant cancer-promoting role of $\mathrm{ER} \alpha$ [22]. Our findings support the hypothesis that aberrant hormone activity, by way of altered receptor expression, might be an important factor in the malignant transformation of ovarian cancer.

Open Access This article is distributed under the terms of the Creative Commons Attribution Noncommercial License which permits any noncommercial use, distribution, and reproduction in any medium, provided the original author(s) and source are credited.

\section{References}

1. Lazannec G (2006) Estrogen receptor beta, a possible tumor suppressor involved in ovarian carcinogenesis. Cancer Lett 231:151-157

2. Pearce ST, Jordan VC (2004) The biological role of estrogen receptors $\alpha$ and $\beta$ in cancer. Crit Rev Oncol Hematol 50:3-22

3. Lindgren PR, Cajander S, Bäckström T et al (2004) Estrogen and progesterone receptors in ovarian epithelial tumors. Mol Cell Endocrinol 221:97-104

4. Pujol P, Rey JM, Nirde P et al (1998) Differential expression of estrogen receptor-alpha and -beta messenger RNAs as a potential marker of ovarian carcinogenesis. Cancer Res 58:5367-5373

5. Rutheford T, Brown WD, Sapi E et al (2000) Absence of estrogen receptor-beta expression in metastatic ovarian cancer. Obstet Gynecol 96:417-421

6. Cunat S, Hoffmann P, Pujol P (2004) Estrogens and epithelial ovarian cancer. Gynecol Oncol 94:25-32

7. Hiller SG, Anderson RA, Williams AR et al (1998) Expression of oestrogen receptor alpha and beta in cultured human ovarian surface epithelial cells. Mol Hum Reprod 4:811-815

8. Brandenberger AW, Tee MK, Jaffe RB (1998) Estrogen receptor alpha (ER-alpha) and beta (ER-beta) mRNAs in normal ovary, ovarian serous cystadenocarcinoma and ovarian cancer cell lines: down-regulation of ER-beta in neoplastic tissues. J Clin Endocrinol Metab 83:1025-1028

9. Kurebayashi J (2003) Endocrine-resistant breast cancer: underlying mechanisms and strategies for overcoming resistance. Breast Cancer 10:112-119

10. Harries M, Kaye SB (2001) Recent advances in the treatment of epithelial ovarian cancer. Expert Opin Investig Drugs 10:1715-1724

11. McClay EF, Albright KD, Jones JA et al (1994) Tamoxifen delays the development of resistance to cisplatin in human melanoma and ovarian cancer cell lines. Br J Cancer 70:449-452

12. Materna V, Liedert B, Homale J et al (2005) Protection of platinum-DNA adduct formation and reversal of cisplatin resistance by anti-MRP2 hammerhead ribozymes in human cancer cells. Int J Cancer 115:393-402

13. Materna V, Stege A, Surowiak P et al (2006) RNA interferencetriggered reversal of $\mathrm{ABCC} 2$-dependent cisplatin resistance in human cancer cells. Biochem Biophys Res Commun 348:153-157
14. Kowalski P, Surowiak P, Lage H (2005) Reversal of different drug-resistant phenotypes by an autocatalytic multitarget multiribozyme directed against the transcripts of the $\mathrm{ABC}$ transporters MDR1/P-gp, MRP2, and BCRP. Mol Ther 11:508-522

15. Surowiak P, Materna V, Kaplenko I et al (2006) ABCC2 (MRP2, cMOAT) can be localized in the nuclear membrane of ovarian carcinomas and correlates with resistance to cisplatin and clinical outcome. Clin Cancer Res 12:7149-7158

16. Györffy B, Surowiak P, Kiesslich O et al (2006) Resistance prediction profile for eleven anticancer agents at clinical concentrations based on the gene expression pattern of thirty cell lines. Int J Cancer 118:1699-1712

17. Sobin LH, Wittekind Ch (eds) (1997) UICC TNM Classification of malignant tumors. Wiley-Liss, New York

18. Shimizu Y, Kamoi S, Amada S et al (1998) Toward the development of a universal grading system of ovarian epithelial carcinoma: Testing of a proposed system in a series of 461 patients with uniform treatment and follow-up. Cancer 82:893901

19. Remmele W, Stenger HE (1987) Recommendation for uniform definition of an immunoreactive score (IRS) for immunohistochemical estrogen receptor detection (ER-ICA) in breast cancer tissue. Pathologe 8:138-140

20. Fitzgibbons PL, Page DL, Weaver D et al (2000) Prognostic factors in breast cancer. college of american pathologists consensus statement 1999. Arch Pathol Lab Med 124:966-978

21. Ogawa Y, Moriya T, Kato Y et al (2004) Immunohistochemical assessment for estrogen receptor and progesterone receptor status in breast cancer: analysis for a cut-off point as the predictor for endocrine therapy. Breast Cancer 11:267-275

22. Burges A, Brüning A, Dannenmann C et al (2010) Prognostic significance of estrogen receptor alpha and beta expression in human serous carcinomas of the ovary. Arch Gynecol Obstet 281:511-517

23. Lee P, Rosen DG, Zhu C et al (2005) Expression of progesterone receptor is favorable prognostic marker in ovarian cancer. Gynecol Oncol 96:671-677

24. Li AJ, Baldwin RL, Karlan BY (2003) Estrogen and progesterone receptor subtype expression in normal and malignant ovarian epithelial cell cultures. Am J Obstet Gynecol 189:22-27

25. Hecht JL, Kotsopoulos J, Hankinson SE et al (2009) Relationship between epidemiological risk and hormone receptor expression in ovarian cancer: results from the Nurses' Health Study. Cancer Epidemiol Biomark Prev 18:1-14

26. Sakaguchi H, Fujimoto J, Aoki I et al (2002) Expression of oestrogen receptor $\mathrm{a}$ and $\mathrm{b}$ in uterine endometrial and ovarian cancers. Eur J Cancer 38:S74-S75

27. Chao KC, Wang PH, Yen MS et al (2005) Role of estrogen and progesterone in the survival of ovarian tumors - a study of the human ovarian adenocarcinoma cell line OC-117-VGH. J Chin Med Assoc 68:360-367

28. Park SH, Cheung LW, Wong AS et al (2008) Estrogen regulates Snail and Slug in the down-regulation of E-cadherin and induces metastatic potential of ovarian cancer cells through estrogen receptor $\alpha$. Mol Endocrinol 22:2085-2098

29. Therasse P, Arbuck SG, Eisenhauer EA et al (2000) New guidelines to evaluate the response to treatment in solid tumors. European Organization for Research and Treatment of Cancer, National Cancer Institute of the United States, National Cancer Institute of Canada. J Natl Cancer Inst 92:205-216 